\title{
PENGARUH TEKS PERANTARA DALAM TERJEMAHAN TIDAK LANGSUNG KEPADA BAHASA MELAYU
}

\section{(The Influence of the Intermediary Text in Indirect Translation into Malay)}

Intan Suraya Zainol

intan_suraya3093@yahoo.com

Haslina Haroon*

haslina@usm.my

Bahagian Pengajian Terjemahan dan Interpretasi, Pusat Pengajian Ilmu Kemanusiaan, Universiti Sains Malaysia.

Pengarang koresponden (Corresponding author): *

Rujukan artikel ini (To cite this article): Intan Suraya Zainol \& Haslina Haroon. (2021). Pengaruh teks perantara dalam terjemahan tidak langsung kepada bahasa Melayu. Melayu: Jurnal Antarabangsa Dunia Melayu, 14(2), 239-262. http://doi. org. 10.37052/jm.14(2)no5

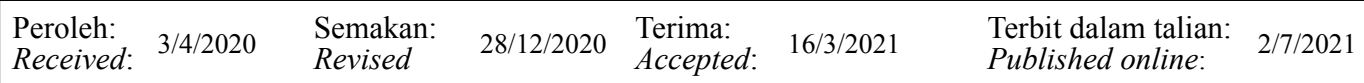

\begin{abstract}
Abstrak
Terjemahan tidak langsung ialah karya terjemahan yang dihasilkan bukan secara langsung daripada teks sumber tetapi secara tidak langsung dengan menggunakan teks perantara. Disebabkan hal ini, timbul kekhuatiran akan wujud perbezaan antara teks terjemahan tidak langsung dengan teks sumber asal. Dengan mengambil kira hal ini, kajian meneliti pengaruh teks perantara dalam terjemahan tidak langsung kepada bahasa Melayu. Kajian ini melibatkan teks terjemahan tidak langsung dalam bahasa Melayu bertajuk Nurani Tanah Melayu, teks perantara dalam bahasa Inggeris bertajuk The Soul of Malaya dan teks sumber dalam bahasa Perancis bertajuk Malaisie. Secara khususnya, kajian ini bertujuan untuk meneliti sama ada penggunaan teks perantara bahasa Inggeris dalam terjemahan tidak langsung kepada bahasa Melayu mempunyai kesan terhadap teks terjemahan, iaitu dari segi
\end{abstract}

(C) Dewan Bahasa dan Pustaka. 2021. This work is licensed under the term of the Creative Commons Attribution (CC BY) (http://creative commons.org/licenses/by/4.0/)

ISSN 1675-6460 e-ISSN 2682-8049 
kesetiaannya pada kandungan teks sumber asal dalam bahasa Perancis. Perbandingan dilakukan antara teks sumber, teks perantara dan teks terjemahan. Kajian ini mendapati bahawa dalam beberapa kes, perbezaan antara teks terjemahan dan teks sumber asal sememangnya timbul dalam terjemahan tidak langsung. Perbezaan ini wujud dalam bentuk penambahan, pengguguran dan pindaan. Walau bagaimanapun, perbezaan yang berlaku bukan disebabkan penggunaan teks perantara semata-mata tetapi juga disebabkan penyesuaian yang dilakukan oleh penterjemah sendiri.

Kata kunci: Terjemahan tidak langsung, Nurani Tanah Melayu, teks perantara, penyesuaian dalam terjemahan, kesan terjemahan

\begin{abstract}
An indirect translation is a translation that is not produced directly from the source text but is instead produced with the help of an intermediary text. As a result of this, there are concerns that the indirect translation will differ from the original source text. Taking this into account, this study attempts to examine the influence of the intermediary text in indirect translation into the Malay language. It involves an indirect translation in Malay entitled Nurani Tanah Melayu, an intermediary text in English entitled The Soul of Malaya and a source text in French entitled Malaisie. More specifically, this study aims to determine whether the use of the English intermediary text in indirect translation into Malay has any effect on the translation in terms of its accuracy to the content of the original source text in French. In order to carry out this study, a comparison is carried out between the source text, the intermediary text and the translation. The findings show that in a number of cases, there are differences between the translation and the original source text, which indeed affects the indirect translation. These differences are in the forms of additions, omissions and alterations. These differences, however, are attributed not only to the use of the intermediary text but also to adjustments made by the translator.
\end{abstract}

Keywords: Indirecttranslation, Nurani Tanah Melayu, intermediary text, adjustments in translation, effects of translation

\title{
PENDAHULUAN
}

Proses terjemahan lazimnya melibatkan pemindahan mesej secara langsung daripada teks sumber kepada teks sasaran atau teks terjemahan. Proses ini melibatkan dua buah teks dan dua bahasa yang berbeza. Proses terjemahan secara terus atau secara langsung daripada teks sumber ini dapat diungkapkan seperti yang berikut: Teks sumber $>$ teks terjemahan. 
Walau bagaimanapun, ada kalanya terjemahan melibatkan bukan sahaja teks sumber dan teks terjemahan tetapi juga teks perantara, iaitu teks yang menjadi penghubung antara teks sumber dengan teks terjemahan. Proses ini dapat diungkapkan seperti yang berikut: Teks sumber $\mathrm{A}>$ teks perantara $\mathrm{B}>$ teks terjemahan $\mathrm{C}$.

Dalam hal ini, teks perantara B merupakan terjemahan daripada teks sumber A. Teks perantara B ini kemudiannya menjadi teks sumber pula kepada teks terjemahan $\mathrm{C}$. Oleh itu, teks terjemahan $\mathrm{C}$ tidak diterjemahkan secara langsung daripada teks sumber A (teks sumber yang asal) tetapi diterjemahkan dengan menggunakan teks perantara B. Produk yang terhasil daripada proses ini, iaitu teks terjemahan $\mathrm{C}$, dirujuk sebagai terjemahan tidak langsung atau indirect translation (Assis Rosa, Pięta \& Maia, 2017).

Kajian oleh Haslina dan Melati (2015), yang meneliti terjemahan novel terbitan Dewan Bahasa dan Pustaka (DBP) dari tahun 1958 hingga 2001, menunjukkan bahawa terdapat beberapa terjemahan yang tidak dihasilkan secara langsung daripada teks sumber yang asal tetapi melibatkan penggunaan teks perantara. Sebagai contoh, novel terjemahan bertajuk Riwayat Mayta yang diterbitkan oleh DBP pada tahun 2001 tidak diterjemahkan terus daripada novel asal dalam bahasa Sepanyol, iaitu Historia de Mayta, tetapi berdasarkan teks dalam bahasa Inggeris bertajuk The Real Life of Alejandro Mayta, yang merupakan terjemahan dalam bahasa Inggeris bagi teks asal dalam bahasa Sepanyol. Dalam kes ini, teks The Real Life of Alejandro Mayta merupakan teks perantara yang menghubungkan teks asal dalam bahasa Sepanyol dengan teks terjemahan dalam bahasa Melayu. Proses terjemahan dalam kes ini dapat diungkapkan seperti yang berikut: bahasa Sepanyol $>$ bahasa Inggeris $>$ bahasa Melayu.

Oleh sebab teks terjemahan tidak langsung dihasilkan berdasarkan sebuah teks perantara, timbul kekhuatiran bahawa teks terjemahan tersebut (teks terjemahan C) akan berubah daripada teks sumber asal (teks sumber A) (Assis Rosa, Pięta \& Maia, 2017; Kadiu, 2016; Li, 2017). Dengan kata lain, terjemahan tidak langsung diandaikan boleh menyebabkan wujudnya perbezaan antara teks terjemahan yang terhasil dengan teks sumber asal.

Kekhuatiran ini timbul kerana kesetiaan pada teks sumber masih menjadi kayu ukur yang penting dalam terjemahan. Kekhuatiran ini menjadi bertambah serius kerana perubahan atau penyesuaian sering dilakukan dalam proses terjemahan, yang menyebabkan kesetiaan teks terjemahan pada teks sumber terjejas. Kadiu (2016: 1) menegaskan bahawa "in every representation of a text in another language modifications of the original occur". Berdasarkan pernyataan ini, dapat disimpulkan bahawa semua bentuk terjemahan melibatkan penyesuaian, tidak kira sama ada terjemahan dilakukan secara langsung atau dilakukan secara tidak langsung, iaitu dengan bantuan teks perantara. Jika sebuah teks perantara yang telah diubah 
kandungannya kemudiannya menjadi teks sumber pula bagi sebuah teks terjemahan yang lain, terdapat kemungkinan bahawa lebih banyak perubahan dan penyesuaian dilakukan. Perubahan yang dilakukan dalam terjemahan teks sumber $\mathrm{A}>$ teks perantara $\mathrm{B}$ dan seterusnya dalam terjemahan teks perantara $\mathrm{B}>$ teks terjemahan $\mathrm{C}$ mungkin akhirnya menyebabkan teks terjemahan $C$ berubah daripada teks sumber $A$ dan menyebabkan kesetiaan teks terjemahan $\mathrm{C}$ pada teks sumber A terjejas dari segi kandungan dan makna.

Dengan mengambil kira perkara ini, kajian ini dilakukan bertujuan untuk meneliti pengaruh teks perantara dalam terjemahan tidak langsung ke dalam bahasa Melayu. Kajian ini melibatkan teks terjemahan tidak langsung dalam bahasa Melayu bertajuk Nurani Tanah Melayu, teks perantara dalam bahasa Inggeris bertajuk The Soul of Malaya dan teks sumber dalam bahasa Perancis bertajuk Malaisie. Secara khususnya, kajian ini bertujuan untuk meneliti sama ada penggunaan teks perantara bahasa Inggeris dalam penghasilan terjemahan tidak langsung dalam bahasa Melayu mempunyai kesan terhadap teks terjemahan, iaitu dari segi kesetiaan teks terjemahan pada kandungan teks sumber asal dalam bahasa Perancis.

\section{TERJEMAHAN TIDAK LANGSUNG}

Terjemahan tidak langsung atau indirect translation ditakrifkan dengan pelbagai cara oleh sarjana yang berbeza. Kittel dan Frank (1991: 3), misalnya, mentakrifkan indirect translation sebagai "the translation based on a source (or sources) which is itself a translation into a language other than the language of the original, or the target language". Berdasarkan takrifan ini, dapat difahami bahawa terjemahan tidak langsung ialah terjemahan kepada bahasa sasaran yang dilakukan berdasarkan teks sumber yang juga merupakan sebuah teks terjemahan daripada sebuah teks sumber asal. Teks yang menjadi teks perantara dalam hal ini dihasilkan dalam bahasa yang tidak sama dengan bahasa sasaran atau pun bahasa sumber asal. Proses ini dapat

diungkapkan seperti yang berikut: teks sumber $\mathrm{A}$ (bahasa $\mathrm{A}$ ) $>$ teks perantara $\mathrm{B}$ (bahasa $\mathrm{B}$ ) $>$ teks terjemahan tidak langsung $\mathrm{C}$ (bahasa $\mathrm{C}$ ).

Landers (2001: 34) juga memberikan takrifan yang hampir sama bagi indirect translation, iaitu "translation into Language C based on a translation into Language B of a source text in Language A". Assis Rosa, Pięta dan Maia (2017: 113) pula mentakrifkan indirect translation ("ITr") sebagai "a translation of a translation". Berdasarkan takrifan yang diberikan, jelas bahawa indirect translation atau terjemahan tidak langsung ialah karya terjemahan yang dihasilkan daripada sebuah teks sumber yang juga merupakan terjemahan daripada sebuah teks sumber yang 
lain. Dalam terjemahan tidak langsung, penterjemah lazimnya tidak menguasai bahasa sumber dan bergantung pada teks perantara untuk memperoleh maklumat daripada teks sumber.

Dalam semua takrifan yang diberikan sebelum ini, terjemahan tidak langsung merujuk teks atau produk yang terhasil daripada penterjemahan yang dilakukan berdasarkan sebuah teks yang juga merupakan sebuah teks terjemahan. Walau bagaimanapun, terjemahan tidak langsung juga boleh merujuk proses, perbuatan atau tindakan yang menyebabkan terhasilnya teks terjemahan tidak langsung. Sebagai contoh, Shuttleworth dan Cowie (1997: 76) mentakrifkan indirect translation sebagai "the procedure whereby a text is not translated directly from an original ST, but via an intermediate translation in another language". Dalam takrifan yang diberikan oleh Hekkanen (2014) pula, indirect translation merujuk perbuatan atau tindakan. Indirect translation ditakrifkan oleh Hekkanen (2014: 48) sebagai "translating a text via a language other than the original language". Oleh itu, jelas bahawa istilah indirect translation boleh merujuk dua perkara, iaitu (i) prosedur yang melibatkan penterjemahan yang dilakukan berdasarkan sebuah teks yang juga merupakan teks terjemahan, dan (ii) teks yang terhasil daripada prosedur tersebut. Dapat dilihat juga bahawa dalam takrifan indirect translation yang diberikan oleh Shuttleworth dan Cowie (1997) ialah istilah intermediate translation atau terjemahan perantara, yang merujuk teks terjemahan yang digunakan sebagai sumber untuk menghasilkan teks terjemahan tidak langsung.

Beberapa orang sarjana yang meneliti isu terjemahan tidak langsung menekankan peranan dan kepentingannya. Secara umumnya, terjemahan tidak langsung membantu menghubungkan budaya yang berbeza (Ringmar, 2007: 1). Secara khususnya pula, terjemahan tidak langsung membantu memperkenalkan sastera daripada satu budaya kepada budaya yang lain. Di Sepanyol misalnya, masyarakat tempatan diperkenalkan kepada sastera China pada abad ke-20 dan abad ke-21 melalui terjemahan karya sastera China dalam bahasa Sepanyol melalui perantaraan bahasa Inggeris atau bahasa Perancis (bahasa China $>$ bahasa Inggeris/Perancis $>$ bahasa Sepanyol). Di China pula, masyarakat tempatan diperkenalkan kepada drama Henrik Ibsen, yang asalnya ditulis dalam bahasa Norway-Denmark, melalui perantaraan bahasa Inggeris (bahasa Norway-Denmark $>$ bahasa Inggeris $>$ bahasa China) (He, 2001: 197). He (2001) menegaskan bahawa daripada 26 terjemahan Ibsen dalam bahasa China, tidak ada satu pun yang diterjemahkan terus daripada teks sumber dalam bahasa NorwayDenmark.

Meskipun terdapat beberapa kelebihan terjemahan tidak langsung, para sarjana juga mengakui bahawa terdapat isu yang timbul akibat penggunaan terjemahan tidak langsung. Terjemahan tidak langsung sering dilihat sebagi satu perkara yang negatif, 
khususnya kerana terjemahan seperti ini tidak dihasilkan terus daripada teks sumber yang sebenar tetapi berdasarkan teks perantara yang merupakan terjemahan daripada teks sumber yang sebenar. Jika dilihat dari segi sejarah, teks terjemahan secara tradisinya tidak dianggap teks yang mempunyai nilai yang tinggi kerana teks ini bukan teks asal, malah merupakan teks yang dihasilkan berdasarkan sebuah teks yang lain. Oleh itu, terdapat kemungkinan teks terjemahan yang terhasil akan berbeza daripada teks sumber. Dengan mengambil kira hal ini, tidak hairanlah jika terjemahan tidak langsung dipandang secara lebih negatif lagi. Hal ini demikian kerana terjemahan tidak langsung dihasilkan berdasarkan karya terjemahan dan cenderung untuk menjadi semakin berbeza daripada teks sumber asal, seperti yang dijelaskan oleh Kadiu (2016: 4): "the translated text is twice removed from the original. It is a translation of a translation: a double translation".

Isu penting dalam hal ini ialah kesetiaan kepada teks sumber, yang masih diberikan penekanan dalam terjemahan (Assis Rosa, Pięta \& Maia, 2017). Secara khususnya, isu yang timbul ialah sejauh mana teks terjemahan tidak langsung mencerminkan teks sumber asal disebabkan penggunaan teks perantara dalam proses terjemahan. Dengan kata lain, oleh sebab teks perantara digunakan dalam proses terjemahan, terdapat kemungkinan bahawa teks terjemahan tidak langsung yang terhasil tidak setia kepada kandungan teks asal atau akan berbeza daripada teks sumber asal, seperti yang dijelaskan oleh Assis Rosa, Pięta dan Maia (2017: 113) dalam petikan berikut: "given an apparently still predominant demand for closeness to the source text (ST), ITr tends to be negatively evaluated because it arguably increases the distance to the ultimate ST...”. Landers (2001) pula menyatakan bahawa proses penghasilan terjemahan tidak langsung berdasarkan sebuah terjemahan boleh disamakan dengan proses penghasilan satu salinan foto berdasarkan satu salinan foto yang lain. Menurut Landers (2001), " $a$ copy of a copy of a copy loses sharpness and detail with each successive passage through the process" (2001: 131). Dengan kata lain, terjemahan tidak langsung cenderung untuk menjadi berbeza daripada teks sumber asal disebabkan penggunaan teks perantara dalam proses terjemahan. Dengan mengambil kira perbincangan ini, kajian ini akan meneliti pengaruh teks perantara dalam penghasilan terjemahan tidak langsung dalam bahasa Melayu, iaitu sama ada penggunaan teks perantara mempengaruhi kesetiaan teks terjemahan pada kandungan teks sumber asal.

\section{METODOLOGI}

Kajian ini merupakan kajian kes yang memberikan fokus pada teks terjemahan tidak langsung dalam bahasa Melayu bertajuk Nurani Tanah Melayu, yang diterjemahkan daripada teks perantara dalam bahasa Inggeris yang bertajuk The Soul of Malaya, 
yang asalnya diterbitkan dalam bahasa Perancis dengan tajuk Malaisie. Proses terjemahan tidak langsung teks Nurani Tanah Melayu dapat diungkapkan seperti berikut: Malaisie (bahasa Perancis) $>$ The Soul of Malaya (bahasa Inggeris) > Nurani Tanah Melayu (bahasa Melayu). Kajian ini bertujuan untuk meneliti sama ada wujud perbezaan antara kandungan teks terjemahan dalam bahasa Melayu dengan teks sumber asal dalam bahasa Perancis disebabkan penggunaan teks perantara bahasa Inggeris dalam proses terjemahan tidak langsung.

Teks terjemahan tidak langsung Nurani Tanah Melayu merupakan hasil terjemahan Muhammad Haji Salleh dan diterbitkan pada tahun 2015 oleh Institut Terjemahan \& Buku Malaysia (ITBM). Dalam prakata, penterjemah menjelaskan bahawa teks Nurani Tanah Melayu diterjemahkan berdasarkan teks bahasa Inggeris bertajuk The Soul of Malaya. Menurut Muhammad Haji Salleh, "oleh sebab penguasaan bahasa Perancis saya sangat asas, saya telah menggunakan terjemahan Eric Sutton dalam bahasa Inggeris, yang diberi judul The Soul of Malaya" (Muhammad, 2015: viii).

The Soul of Malaya merupakan teks terjemahan dalam bahasa Inggeris yang dihasilkan oleh Eric Sutton berdasarkan teks dalam bahasa Perancis bertajuk Malaisie. The Soul of Malaya diterbitkan kali pertama pada tahun 1931 oleh Elkin Mathews \& Marrot di London. Dalam kajian ini, teks yang digunakan ialah teks The Soul of Malaya yang diterbitkan semula oleh Editions Didier Millet di Singapura pada tahun 2015.

Malaisie pula merupakan hasil karya Henri Fauconnier yang ditulis dalam bahasa Perancis. Malaisie diterbitkan pada tahun 1930 oleh Librairie Stock di Paris. Pada tahun yang sama, Malaisie telah dianugerahkan Hadiah Prix Goncourt, iaitu salah satu anugerah tertinggi dalam bidang kesusasteraan di Perancis. Novel Malaisie, yang berlatarbelakangkan Tanah Melayu pada tahun 1920-an, mengisahkan kehidupan dua orang warga Perancis, iaitu Rolain, pemilik ladang getah di Pantai Timur Semenanjung Tanah Melayu, dan rakannya, Lescale.

Oleh sebab kajian ini meneliti sama ada wujud perbezaan antara teks terjemahan dalam bahasa Melayu dengan teks sumber asal dalam bahasa Perancis disebabkan penggunaan teks perantara bahasa Inggeris dalam proses terjemahan tidak langsung, perkara pertama yang perlu dilihat adalah sama ada terdapat perbezaan dari segi kandungan teks terjemahan dalam bahasa Melayu dan teks sumber asal dalam bahasa Perancis. Jika perbezaan ini wujud, perkara yang seterusnya yang perlu dikenal pasti ialah bentuk perbezaan atau perubahan yang telah menyebabkan wujudnya perbezaan ini. Akhir sekali, perkara yang perlu ditentukan adalah sama ada perbezaan tersebut wujud disebabkan penggunaan teks perantara dalam bahasa Inggeris. Oleh yang demikian, kaedah analisis teks dan perbandingan teks dimanfaatkan dalam kajian ini 
dan melibatkan bukan sahaja teks terjemahan dalam bahasa Melayu dan teks sumber asal dalam bahasa Perancis tetapi juga teks perantara dalam bahasa Inggeris.

Untuk melaksanakan kajian ini, setiap ayat dalam teks terjemahan dalam bahasa Melayu dipadankan dengan pasangannya dalam teks perantara bahasa Inggeris dan teks sumber bahasa Perancis. Langkah ini membolehkan pengkaji membandingkan ketiga-tiga teks untuk meneliti dan mengenal pasti persamaan dan perbezaan antara ketiga-tiga teks. Dalam konteks kajian ini, perbezaan antara teks ditentukan dengan meneliti perubahan atau penyesuaian yang dilakukan oleh penterjemah. Untuk tujuan ini, kerangka teknik penyesuaian (techniques of adjustment) yang dikemukakan oleh Nida (1964) digunakan. Menurut Nida (1964), terdapat tiga bentuk penyesuaian atau perubahan yang boleh dilakukan oleh penterjemah untuk melakukan terjemahan, iaitu (a) penyesuaian dalam bentuk penambahan, (b) penyesuaian dalam bentuk pengguguran, dan (c) penyesuaian dalam bentuk pindaan. Penyesuaian dalam bentuk penambahan bermaksud penterjemah memasukkan maklumat lain selain yang telah sedia ada dalam teks sumber. Penyesuaian dalam bentuk pengguguran pula bermaksud bahawa penterjemah menghilangkan maklumat yang terdapat pada teks sumber. Akhir sekali, penyesuaian dalam bentuk pindaan bermaksud bahawa penterjemah meminda atau mengubah maklumat dalam teks sumber. Setiap bentuk penyesuaian ini ditentukan dengan meneliti perubahan yang berlaku berdasarkan perbandingan yang dilakukan.

\section{ANALISIS DAN PERBINCANGAN}

Berdasarkan perbandingan dan analisis yang dilakukan, didapati bahawa secara amnya teks terjemahan dalam bahasa Melayu memperlihatkan persamaan dengan teks sumber asal dalam bahasa Perancis. Walau bagaimanapun, perbandingan yang dilakukan juga menunjukkan bahawa dalam beberapa kes, terdapat perbezaan antara kandungan teks terjemahan dalam bahasa Melayu jika dibandingkan dengan teks sumber asal dalam bahasa Perancis.

Perbincangan yang seterusnya pada bahagian ini akan memaparkan contoh yang menunjukkan perbezaan antara teks terjemahan dalam bahasa Melayu dengan teks sumber asal dalam bahasa Perancis. Contoh yang ditunjukkan akan memaparkan ekstrak daripada teks sumber dalam bahasa Perancis (P), iaitu Malaisie, yang disertakan glos dalam bahasa Melayu, ekstrak daripada teks perantara dalam bahasa Inggeris (I), iaitu The Soul of Malaya, dan ekstrak daripada teks terjemahan dalam bahasa Melayu (M), iaitu Nurani Tanah Melayu. 
Dalam membincangkan contoh yang diekstrak, beberapa rujukan digunakan untuk menjelaskan perbezaan dari segi penambahan, pengguguran dan pindaan. Bagi perkataan dalam bahasa Perancis, rujukan yang digunakan ialah Kamus Perancis Melayu Dewan (2002). Seterusnya, takrifan bagi perkataan dalam bahasa Inggeris ditentusahkan dengan merujuk beberapa kamus bahasa Inggeris dalam talian, misalnya Collins English Dictionary, Merriam-Webster Dictionary dan Oxford Learner's Dictionaries. Akhir sekali, bagi perkataan dalam bahasa Melayu, rujukan yang digunakan ialah rujukan dalam talian, iaitu Pusat Rujukan Persuratan Melayu, Dewan Bahasa dan Pustaka.

Perbezaan antara teks terjemahan dalam bahasa Melayu dengan teks sumber asal dalam bahasa Perancis dapat dilihat dalam contoh yang dipaparkan. Dalam Contoh 1, Lescale, yang menjadi pengisah dalam novel ini, menceritakan perasaannya apabila dia bertembung semula dengan Rolain setelah mereka terpisah akibat peperangan.

Dalam teks asal dalam bahasa Perancis, Lescale berasa amat terharu dan mempunyai perasaan "ému" kerana berjumpa kembali rakannya, Rolain. Perkataan "ému", menurut Kamus Perancis Melayu Dewan, membawa maksud "terharu, tersentuh hati, susah hati, penuh keharuan" (Ému, 2002: 223).

Dalam teks perantara dalam bahasa Inggeris pula, penterjemah memberikan gambaran yang lebih jelas tentang keadaan Lescale yang berasa terharu dengan pertemuan itu. Lescale digambarkan sebagai seorang yang bukan sahaja terharu (overcome with emotion), malah disebabkan perasaan terharunya itu, dia berdiri terpaku (stood still) dan tidak turut serta meluru ke arah bar bersama-sama para pengunjung lain. Jika diteliti, gambaran Lescale yang berdiri terpaku ini tiada dalam

\section{Contoh 1}

P: $\quad$ AA] [ce] [moment] [il y eut] [une] [ruée] [vers] [le bar]. [Et] [moi], [ému], [j'hésitais] [à aller] [vers] [celui] [que] [j'aimais] [dans]

[mon souvenir] [comme] [on] [aime] [la mémoire] [d'un mort]. (hlm. 10)

[Pada] [itu] [ketika] [terdapat] [satu] [rusuhan] [ke arah] [bar]. [Dan] [saya], [terharu],

[saya teragak-agak] [untuk pergi] [ke arah] [orang] [yang] [saya sayangi] [dalam] [ingatan saya] [seperti] [kita] [sayang] [ingatan] [satu kematian].

I: At that moment there was a rush for the bar. But I stood still, overcome with emotion, hesitating to approach one whom I cherished in my mind as I would cherish the memory of a dead friend. (hlm. 9) 
teks asal bahasa Perancis. Penyesuaian dalam bentuk penambahan ini telah dibuat oleh penterjemah teks perantara dalam bahasa Inggeris.

Penterjemah teks bahasa Melayu pula menggambarkan bahawa Lescale "masih berdiri, dilanda perasaan" dan tidak meluru ke arah bar. Jika dibandingkan terjemahan dalam bahasa Melayu ini dengan teks sumber dalam bahasa Perancis, jelas bahawa wujud perbezaan antara kedua-duanya, iaitu melalui penambahan ungkapan "masih berdiri" dalam terjemahan bahasa Melayu. Maklumat ini tidak wujud dalam teks asal bahasa Perancis. Pada masa yang sama, jelas juga bahawa teks terjemahan dalam bahasa Melayu ini mencerminkan teks perantara, iaitu "masih berdiri" yang merupakan terjemahan daripada ungkapan "stood still" dalam teks bahasa Inggeris.

Jelas melalui contoh ini terdapat perbezaan antara teks terjemahan dalam bahasa Melayu dengan teks sumber asal dalam bahasa Perancis. Jelas juga bahawa perbezaan ini berlaku disebabkan pengaruh teks perantara. Secara khusus, perbezaan ini berlaku kerana penterjemah teks bahasa Melayu bergantung pada teks perantara dalam bahasa Inggeris yang telah disesuaikan dengan penambahan. Contoh ini jelas menunjukkan bahawa penggunaan teks perantara dalam terjemahan tidak langsung telah menyebabkan berlakunya perbezaan antara kandungan teks terjemahan dalam bahasa Melayu dengan teks sumber asal dalam bahasa Inggeris. Walau bagaimanapun, perlu dinyatakan juga bahawa penambahan maklumat seperti yang dipaparkan dalam contoh ini menyebabkan mesej yang ingin disampaikan tentang keadaan Lescale menjadi lebih jelas, khususnya melalui gambaran keadaannya yang berdiri terpaku yang tiada dalam teks sumber asal dalam bahasa Perancis.

Petikan dalam Contoh 2 pula menceritakan perasaan Lescale ketika kali pertama dia bermalam di dalam hutan. Lescale menerangkan bahawa suasana pada waktu malam di dalam hutan begitu sejuk dan damai sekali dan hal yang demikian menyebabkan dia teringat kali pertama dia menaiki kapal yang m'avait amené. Perkataan $m$ 'avait merupakan gabungan perkataan me yang bermaksud "saya" ( $M e$, 2002: 402), dan perkataan avait berasal daripada perkataan avoir yang membawa maksud "sudah" (Avoir, 2002: 49). Perkataan amené pula berasal daripada perkataan amener yang bermaksud "membawa, membawa bersama" (Amener, 2002: 21). Hal ini bermaksud bahawa suasana malam yang sejuk dan damai itu mengingatkan Lescale pada masa dia menaiki kapal yang telah membawanya. Lescale sebenarnya menaiki kapal yang telah membawanya ke Tanah Melayu, namun hal ini tidak dinyatakan secara terang-terangan dalam teks sumber dalam bahasa Perancis.

Hala tuju kapal yang dinaiki oleh Lescale, walau bagaimanapun, dinyatakan secara eksplisit oleh penterjemah teks bahasa Inggeris, iaitu melalui penyesuaian dalam bentuk penambahan perkataan "East" dalam teks bahasa Inggeris. Perkara 


\section{Contoh 2}

P: [Cela] [me rappelait] [ma première nuit] [à bord] [du paquebot] [qui] [m'avait amené]. (hlm. 29)

[Perkara itu] [mengingatkan saya] [malam pertama saya] [di atas] [kapal wap] [yang]

[telah membawa saya].

I: It recalled my first night on the steamer that had brought me East. (hlm. 20)

M: Saya teringat akan malam pertama di atas kapal wap yang melayarkan saya ke Timur. (hlm. 15)

yang sama dilakukan oleh penterjemah teks bahasa Melayu, yang menggunakan perkataan "Timur" dalam terjemahannya. Oleh itu, jika dibandingkan terjemahan dalam bahasa Melayu ini dengan teks sumber dalam bahasa Perancis, jelas bahawa wujud perbezaan antara kedua-duanya, iaitu penambahan ungkapan "ke Timur" dalam terjemahan bahasa Melayu. Jelas juga bahawa perbezaan ini berlaku disebabkan pergantungan penterjemah teks bahasa Melayu pada teks perantara dalam bahasa Inggeris yang mengandungi penambahan tersebut. Sekali lagi, dapat dilihat bahawa penggunaan teks perantara dalam terjemahan tidak langsung sememangnya menyebabkan wujudnya perbezaan antara teks terjemahan dalam bahasa Melayu dengan teks sumber asal dalam bahasa Perancis. Walau bagaimanapun, perlu ditekankan juga bahawa penambahan yang dilakukan menyebabkan hala tuju kapal yang dinaiki oleh Lescale menjadi lebih jelas.

Petikan dalam Contoh 3 pula merupakan kata-kata yang diucapkan oleh Stark, pengurus ladang Rolain, kepada pembantu rumahnya, iaitu seorang lelaki berbangsa Cina bernama Ha Hek. Ketika Rolain dan Lescale tiba di rumah Stark, Ha Hek tidak keluar untuk menyambut tetamu tuannya, malah hanya muncul setelah dipanggil oleh Stark sendiri. Hal ini menimbulkan kemarahan Stark, seperti yang dapat dilihat dalam Contoh 3.

Dalam keadaannya yang marah, Stark melemparkan soalan kepada Ha Hek, "Tu fumais ton opium?" Perkataan tu merujuk "engkau, kamu, awak" (Tu, 2002, hlm. 631), manakala perkataan fumais berasal daripada perkataan fumer yang membawa maksud "mengepulkan asap" atau "merokok" (Fumer, 2002: 291). Seterusnya, perkataan ton membawa maksud "(kepunyaan) awak" (Ton, 2002: 615), manakala 


\section{Contoh 3}

P: $\quad$ “...[Tu] [dormais]? [Tu] [fumais] [ton opium] ?... [Ces] [sacrés]

[Chinois], [ça se vautre] [dans] le vice], ...”. (hlm. 22)

...[Kamu] [tidurkah]? [Kamu] [menghisap] [candu kamu] ?... [Itu] [terkutuk] [orang-orang Cina], [ia bergelumang] [dalam] [kejahatan]

I: “...Were you asleep, or smoking your filthy opium?... Those blasted Chinese wallow in vice...”. (hlm. 17)

M: “...Kamu tidurkah? Atau sedang menghisap candu busuk kamu? Dia ini bergelumang dengan kejahatan...”. (hlm. 11)

perkataan opium membawa maksud "candu, madat" (Opium, 2002: 440). Oleh itu, ungkapan "Tu fumais ton opium?" dalam petikan ini merupakan soalan yang bermaksud "Awak menghisap candu awak?"

Dalam teks perantara bahasa Inggeris, Stark bertanya kepada Ha Hek: "Were you...smoking your filthy opium?" Di sini, penterjemah teks bahasa Inggeris telah melakukan penambahan dengan memasukkan perkataan filthy sebelum perkataan "opium". Perkataan filthy membawa maksud sesuatu yang sangat kotor dan tidak menyenangkan atau satu perkataan yang digunakan secara tidak formal untuk menunjukkan perasaan marah (Filthy: t.t.).

Dapat dilihat juga dalam teks terjemahan bahasa Melayu bahawa Stark bertanya kepada Ha Hek sama ada dia sedang menghisap "candu busuk". Di sini, teks terjemahan bahasa Melayu menyamai kandungan teks terjemahan bahasa Inggeris, iaitu kedua-duanya mempunyai kata adjektif, iaitu filthy dan "busuk" yang masingmasing berfungsi untuk menerangkan perkataan "opium" dan "candu". Dapat dilihat juga bahawa terjemahan dalam bahasa Melayu menunjukkan perbezaan dari segi kandungannya dengan teks asal dalam bahasa Perancis. Perbezaan ini disebabkan oleh penyesuaian dalam bentuk penambahan maklumat yang telah dilakukan dalam teks perantara bahasa Inggeris. Dalam hal ini, teks perantara sememangnya menyumbang kepada perbezaan yang wujud antara teks terjemahan dalam bahasa Melayu dengan teks asal dalam bahasa Perancis. Walau bagaimanapun, dapat dilihat bahawa penambahan ini menjadikan mesej yang ingin disampaikan, iaitu perasaan marah Stark terhadap Ha Hek yang menghisap candu, menjadi lebih jelas. 


\section{Contoh 4}

P: [Les tambourineurs] [tapaient] [les tam-tams] [de] [leurs] [doigts] [secs]. (hlm. 77)

[para pemukul gendang] [memukul] [gendang] [dengan] [mereka] [jari-jari] [kering]

I: $\quad$ The drummers scraped the tom-toms... (hlm. 45)

M: Pemukul gendang menggeserkan kulit gendangnya... (hlm. 41)

Petikan dalam Contoh 4 pula menceritakan suasana perayaan Deepavali yang disambut di Tanah Melayu. Lescale dan Rolain diundang untuk menyertai perayaan Deepavali bersama-sama pekerja Tamil mereka. Oleh itu, Lescale dan Rolain pergi ke kuil untuk melihat sendiri perayaan masyarakat India ini.

Dalam teks bahasa Perancis, pemukul gendang di kuil dikatakan memukul gendang dengan menggunakan "leurs doigts secs". Menurut Kamus Perancis Melayu Dewan, perkataan leurs berasal daripada perkataan leur yang membawa maksud "mereka" (Leur, 2002: 377). Perkataan doigts pula merupakan bentuk jamak bagi perkataan doigt yang membawa maksud "jari" (Doigt, 2002: 199), manakala perkataan secs berasal daripada perkataan sec yang bermaksud "kering" (Sec, 2002: 570).

Dapat dilihat bahawa huraian berkaitan "leurs doigts secs" ("jari-jari mereka yang kering") tidak dikekalkan dalam teks bahasa Inggeris mahupun dalam teks bahasa Melayu. Disebabkan hal ini, teks terjemahan dalam bahasa Melayu jelas berbeza kandungannya daripada teks asal dalam bahasa Perancis. Perbezaan berlaku disebabkan pengguguran yang dilakukan dalam teks bahasa Inggeris dan juga disebabkan pergantungan penterjemah bahasa Melayu pada teks perantara bahasa Inggeris. Sekali lagi, jelas bahawa penggunaan teks perantara dalam terjemahan tidak langsung sememangnya menyebabkan wujudnya perbezaan antara teks bahasa Melayu dan teks sumber asal dalam bahasa Perancis. Perlu dinyatakan bahawa pengguguran yang berlaku secara amnya tidak menjejaskan makna yang ingin disampaikan. Walau bagaimanapun, huraian tentang pekerja Tamil dalam teks bahasa Melayu menjadi kurang terperinci jika dibandingkan dengan huraian dalam teks asal dalam bahasa Perancis.

Petikan yang seterusnya, Contoh 5, menceritakan situasi di rumah pengurus ladang Rolain, iaitu Stark, ketika Lescale, Rolain dan Stark mengadakan perbincangan tentang bayaran gaji buruh. Dalam petikan ini, Stark berasa kecewa apabila Rolain 


\section{Contoh 5}

P: [Stark] [nous] [suivait] [en hochant] [la tête]. (hlm. 23)

[Stark] [kami] [mengikuti] [sambil menggelengkan] [kepala]

I: $\quad$ Stark followed us, crestfallen. (hlm. 17)

M: Stark mengikuti kami, penuh kecewa. (hlm. 12)

memberitahunya bahawa gaji buruh di ladang tidak dapat dibayar tepat pada masanya. Hati Stark bertambah runsing memandangkan para pekerjanya akan menyambut perayaan Deepavali dan perlu menggunakan wang untuk membuat persediaan bagi menyambut perayaan Deepavali.

Dalam teks sumber bahasa Perancis, kekecewaan Stark digambarkan melalui perbuatannya, "hochant la tête". Menurut Kamus Perancis Melayu Dewan, ungkapan "hocher la tête" membawa maksud "menggelengkan kepala" (Hocher, 2002: 321). Oleh itu, kekecewaan Stark dalam teks sumber bahasa Perancis digambarkan melalui perbuatan menggelengkan kepala.

Walau bagaimanapun, dalam teks perantara bahasa Inggeris, kekecewaan Stark digambarkan bukan melalui perbuatannya seperti dalam teks bahasa Perancis tetapi melalui perasaannya, iaitu melalui penggunaan perkataan crestfallen yang bermaksud "sedih" dan "kecewa" (Crestfallen, t.t.). Dalam hal ini, maklumat yang terdapat dalam teks sumber bahasa Perancis, iaitu "hochant la tête" ("menggelengkan kepala"), dipinda menjadi crestfallen (kecewa) dalam teks bahasa Inggeris.

Seterusnya, dalam terjemahan dalam bahasa Melayu, kekecewaan Stark digambarkan melalui ungkapan "penuh kecewa", yang mencerminkan dengan tepat maklumat yang terdapat dalam teks perantara bahasa Inggeris, iaitu "crestfallen". Sekali lagi, teks terjemahan dalam bahasa Melayu menunjukkan perbezaan jika dibandingkan dengan teks sumber dalam bahasa Perancis. Perbezaan ini berlaku disebabkan pindaan yang dilakukan pada teks bahasa Inggeris dan pergantungan penterjemah teks bahasa Melayu pada teks perantara bahasa Inggeris. Kekecewaan Stark yang digambarkan melalui perbuatannya dalam teks sumber bahasa Perancis telah dipinda dan digambarkan dalam teks terjemahan bahasa Melayu melalui perasaannya. Dalam contoh ini, penggunaan teks perantara dalam terjemahan tidak langsung sememangnya menyumbang kepada perbezaan antara teks terjemahan dalam bahasa Melayu dengan teks sumber asal dalam bahasa Perancis. Perbezaan ini, 
walau bagaimanapun, tidak menjejaskan makna yang ingin disampaikan kerana keduadua teks berjaya menyampaikan mesej tentang kekecewaan Stark.

Petikan dalam Contoh 6 pula menggambarkan tingkah laku salah seorang pekerja Tamil yang menjadi wakil buruh di ladang Rolain. Pekerja tersebut cuba untuk memberitahu Rolain bahawa kekecohan telah berlaku di ladangnya.

Untuk menunjukkan keghairahan pekerja tersebut bagi menerangkan perkara yang sebenarnya berlaku di ladang, pekerja tersebut digambarkan oleh Lescale sebagai "pût parler indéfiniment sans respirer". Perkataan pût berasal daripada perkataan pouvoir yang membawa maksud "dapat, boleh, berupaya, mampu" (Pouvoir, 2002, hlm. 492), manakala perkataan parler membawa maksud "bercakap, bertutur" (Parler, 2002: 454). Seterusnya, perkataan indéfiniment membawa maksud "tempoh masa yang tidak pasti, tidak terbatas, untuk selama-lamanya, terus-menerus" (Indéfiniment, 2002: 342), manakala perkataan respirer membawa maksud "bernafas" (Respirer, 2002: 547). Oleh itu, ungkapan "pût parler indéfiniment sans respirer" dalam petikan ini membawa maksud "boleh bercakap terus-menerus tanpa bernafas".

Perkara yang sama dinyatakan dalam teks perantara bahasa Inggeris, iaitu "he talked and talked and seemed to draw no breath". Pengulangan perkataan talked dalam teks perantara bahasa Inggeris menunjukkan bahawa pekerja tersebut bercakap tanpa henti. Jika diteliti, dapat dilihat bahawa tidak seperti contoh sebelumnya teks perantara bahasa Inggeris ini menunjukkan perbezaan dengan teks sumber bahasa Perancis melalui penambahan, pengguguran dan pindaan, teks perantara dalam Contoh 6 mencerminkannya dengan tepat seperti kandungan teks sumber bahasa Perancis.

Mesej yang disampaikan dalam teks sumber bahasa Perancis dan teks terjemahan bahasa Inggeris juga disampaikan dalam teks terjemahan bahasa Melayu. Walau bagaimanapun, mesej ini disampaikan oleh penterjemah bahasa Melayu bukan

\section{Contoh 6}

P: $\quad$ [Il] [semblait] [qi'il] [pût] [parler] [indéfiniment] [sans] [respirer]. (hlm. 36)

[Dia] [kelihatan] [seperti dia] [boleh] [bercakap] [selama-lamanya] [tanpa] [bernafas]

I: He talked and talked and seemed to draw no breath. (hlm. 24)

M: Kelihatan seperti da'i yang dapat bercakap tanpa henti, tanpa perlu bernafas. (hlm. 19) 
sahaja melalui ungkapan "dapat bercakap tanpa henti", yang mencerminkan dengan tepat ungkapan "pût parler indéfiniment sans respirer" dan "he talked and talked and seemed to draw no breath", tetapi juga melalui penambahan ungkapan "seperti da'i". Perkataan "da'i" sebenarnya berasal daripada bahasa Arab dan membawa maksud 'pendakwah' (Dai, t.t.). Oleh itu, penterjemah ingin menyampaikan mesej bahawa pekerja berkenaan bercakap tanpa henti seperti seorang pendakwah yang menyampaikan dakwah. Jika dibandingkan teks terjemahan bahasa Melayu dengan teks sumber asal dalam bahasa Perancis, jelas bahawa terdapat perbezaan antara kedua-dua teks ini. Perbezaan ini wujud disebabkan penambahan yang dilakukan oleh penterjemah dalam teks terjemahan bahasa Melayu, dan bukan disebabkan penggunaan teks perantara. Dengan kata lain, perbezaan antara teks terjemahan bahasa Melayu dan teks sumber bahasa Perancis berlaku disebabkan faktor penterjemah sendiri, iaitu melalui tindakan penterjemah yang melakukan penambahan pada teks terjemahannya. Dapat dilihat juga bahawa walaupun teks terjemahan bahasa Melayu berbeza kandungannya dengan teks sumber asal dalam bahasa Perancis, penambahan yang dilakukan dalam bentuk perumpamaan tersebut menjadikan penyampaian mesej lebih jelas.

Petikan dalam Contoh 7 pula menerangkan kejadian yang berlaku pada hari pembayaran gaji kepada buruh di ladang yang diuruskan oleh Potter, bekas majikan Lescale. Salah satu tugas Potter ialah menyerahkan gaji kepada para buruh. Peluang ini sering digunakan oleh Potter untuk menyebut kesalahan yang dilakukan oleh buruh-buruh tersebut. Dalam contoh yang dipaparkan, salah seorang buruh yang melakukan kesalahan berat telah dipotong gajinya sebanyak lima dolar, lalu wang sebanyak lima dolar diambil semula oleh Potter daripada buruh itu. Potter, walau bagaimanapun, menafikan bahawa duit lima dolar tersebut diambil untuk kegunaannya sendiri. Petikan dalam Contoh 7 menunjukkan penafian Potter.

Penafian Potter dalam hal ini dapat dilihat bukan sahaja melalui ayat "Jen 'ais pas le droit

\section{Contoh 7}

P: “... [Non]. [Je] [n'ais pas] [le droit] [de le garder]”. (hlm. 44)

[Tidak]. [Saya] [tidak mempunyai] [hak] [untuk menyimpannya].

I: “...No, I have no right to keep it...”. (hlm. 28)

M: “...Aku tidak berhak menyimpannya...”. (hlm. 23) 
de le garder" ("Saya tidak mempunyai hak untuk menyimpannya") tetapi juga melalui kata nafi Non pada awal ayat. Menurut Kamus Perancis Melayu Dewan, perkataan non membawa maksud "tidak, bukan" (Non, 2002: 431). Penafian keras Potter ini juga dicerminkan dalam teks perantara bahasa Inggeris, iaitu melalui penggunaan ayat " $I$ have no right to keep it" dan penggunaan kata nafi No pada awal ayat.

Dapat dilihat dalam contoh yang dipaparkan bahawa penterjemah teks terjemahan bahasa Melayu mengekalkan penafian Potter, iaitu melalui ayat "Aku tidak berhak menyimpannya". Walau bagaimanapun, penterjemah telah menggugurkan penggunaan kata nafi pada awal ayat. Pengguguran ini menyebabkan teks terjemahan dalam bahasa Melayu kelihatan berbeza daripada teks sumber asal dalam bahasa Perancis. Walau bagaimanapun, seperti juga dalam Contoh 6 , perbezaan antara teks terjemahan dalam bahasa Melayu dan teks sumber asal dalam bahasa Perancis bukanlah disebabkan teks perantara tetapi disebabkan penterjemah sendiri yang menggugurkan kata nafi tersebut. Pengguguran kata nafi tersebut, walau bagaimanapun, tidak menjejaskan mesej keseluruhan, iaitu penafian Potter tentang wang yang diambilnya.

Petikan dalam contoh yang seterusnya, Contoh 8 , menggambarkan kemarahan Stark terhadap pembantu rumahnya, Ha Hek, seperti yang telah diterangkan dalam Contoh 3. Kemarahan Stark menyebabkan dia menghamburkan kata-kata kesat kepada Ha Hek.

Dalam teks sumber bahasa Perancis, Stark yang berang merujuk orang-orang Cina sebagai "ces sacrés Chinois" ("orang-orang Cina yang terkutuk itu"). Kemarahan Stark dizahirkan melalui kata adjektif sacrés dalam bahasa Perancis. Berdasarkan Kamus Perancis Melayu Dewan, perkataan sacrés merupakan kata adjektif yang

\section{Contoh 8}

P: “... [Tu] [dormais]? [Tu] [fumais] [ton opium] ?... [Ces sacrés] [Chinois], [ça se vautre] [dans] le vice], ...”. (hlm. 22)

[Kamu] [tidurkah]? [Kamu] [menghisap] [candu kamu] ?... [Itu terkutuk] [orangorang Cina], [ia bergelumang] [dalam] [kejahatan]

I: “...Were you asleep, or smoking your filthy opium?... Those blasted Chinese wallow in vice...". (hlm. 17)

M: “...Kamu tidurkah? Atau sedang menghisap candu busuk kamu? Dia ini bergelumang dengan kejahatan...". (hlm. 11) 
membawa maksud "terkutuk, terlaknat" (Sacré, 2002: 563). Dalam teks bahasa Inggeris pula, Stark merujuk orang-orang Cina sebagai "those blasted Chinese". Berdasarkan Oxford Learner's Dictionaries, kata adjektif bahasa Inggeris blasted lazimnya digunakan untuk menzahirkan perasaan marah (Blasted, t.t.).

Dapat dilihat daripada petikan yang ditunjukkan bahawa terdapat perbezaan antara kandungan teks terjemahan bahasa Melayu dengan teks sumber asal dalam bahasa Perancis. Penterjemah melakukan pindaan pada teks terjemahan dengan menggantikan rujukan kepada orang-orang Cina dengan kata ganti nama "dia", yang merujuk kepada Ha Hek sahaja. Sama juga seperti Contoh 6 dan 7, perbezaan yang berlaku bukan disebabkan teks perantara tetapi disebabkan penterjemah sendiri yang meminda maklumat berkenaan. Perlu dinyatakan juga bahawa pindaan yang dilakukan pada teks terjemahan bahasa Melayu menyebabkan perasaan marah Stark pada Ha Hek menjadi kurang terserlah.

Contoh yang seterusnya, Contoh 9, menggambarkan salah satu ritual yang dilakukan oleh buruh Tamil di ladang Rolain ketika mereka menyambut perayaan keagamaan mereka.

Masyarakat India yang bekerja sebagai buruh kebanyakannya terdiri daripada golongan "paria", yang ditakrifkan sebagai "orang atau golongan yang paling rendah kastanya di India" ("Paria", t.t.a). Berdasarkan Kamus Perancis Melayu Dewan, perkataan "paria" bermaksud "seseorang yang dihina oleh masyarakat" (Paria, 2002: 454). Perkataan "paria" yang digunakan dalam teks sumber bahasa Perancis diulang

\section{Contoh 9}

P: [On cassa] [des noix de coco] [devant] [les idoles] [rutilantes] [et] [la pierre] [modeste] [qui] [représente] [le dieu] [des parias]. (hlm. 76)

[Dipecahkan] [kelapa] [di hadapan] [patung] [bercahaya] [dan] [batu] [lebih kecil]

[yang] [mewakili] [tuhan] [kepada pariah].

I: Coconut were broken in front of the glittering idols and the modest stone that represents the god of the pariahs. (hlm. 44)

M: Kelapa pula dipecahkan di hadapan patung-patung yang bergemelapan dan sebutir batu bersaiz sederhana yang mewakili dewa kaum harijan. (hlm. 41) 
penggunaannya dalam teks perantara bahasa Inggeris, iaitu melalui penggunaan perkataan pariahs, yang membawa maksud yang sama, iaitu "a member of a low caste in Southern India" (Paria, t.t.b).

Penterjemah teks bahasa Melayu, walau bagaimanapun, tidak mengekalkan penggunaan perkataan "paria" yang sememangnya wujud dalam bahasa Melayu tetapi sebaliknya menggunakan perkataan "harijan". Perkataan "harijan" sebenarnya bukanlah merupakan kosa kata yang terdapat dalam bahasa Melayu. Walau bagaimanapun, perkataan "harijan" membawa maksud yang hampir sama seperti perkataan "pariah", iaitu "a member of the outcaste group in India' (Harijan, t.t.a). Diandaikan bahawa penterjemah melakukan pindaan dengan menggantikan perkataan "pariah" dengan perkataan "harijan" kerana perkataan "harijan" mempunyai konotasi yang lebih positif jika dibandingkan dengan perkataan "pariah". Secara khususnya, perkataan "harijan" merupakan perkataan dalam bahasa Hindi yang secara literalnya membawa maksud "man of God" (Harijan, t.t.b), iaitu daripada perkataan "hari" (Tuhan/Visynu) + "jan” (manusia/anak). Penterjemah dikatakan melakukan pindaan di sini kerana beliau tidak menggunakan perkataan "paria" yang sememangnya sudah wujud dalam bahasa Melayu, tetapi menggantikannya dengan perkataan "harijan". Jelas wujud perbezaan antara teks terjemahan bahasa Melayu dengan teks sumber bahasa Perancis disebabkan pindaan yang dilakukan oleh penterjemah. Walau bagaimanapun, teks perantara bukanlah faktor yang menyebabkan wujudnya perbezaan antara teks terjemahan bahasa Melayu dengan teks sumber asal dalam bahasa Perancis. Walaupun demikian, pindaan yang dilakukan menyebabkan konotasi negatif yang wujud dalam teks bahasa Perancis dan teks bahasa Inggeris tidak lagi wujud disebabkan penggunaan perkataan yang berkonotasi positif.

Petikan dalam contoh yang terakhir, Contoh 10, menceritakan kejadian pada malam pertama Lescale tidur di dalam hutan dengan ditemani Smail, pembantu rumah Rolain yang berbangsa Melayu.

Dalam teks sumber bahasa Perancis, digambarkan bahawa Smail "avait éteint les lampes" ('telah memadamkan lampu'). Perkataan éteint yang berasal daripada perkataan éteindre membawa maksud "mematikan, memadamkan" (Éteindre, 2002: 246), manakala perkataan lampes berasal daripada perkataan lampe membawa maksud "lampu" (Lampe, 2002: 372). Teks perantara dalam bahasa Inggeris mencerminkan dengan tepat kandungan teks sumber dalam bahasa Perancis, yang mana kata kerja "put out" yang digunakan oleh penterjemah teks perantara membawa maksud yang sama seperti perkataan éteint, iaitu "mematikan atau memadamkan" (Put out, t.t.). Dalam kedua-dua teks sumber dan teks perantara, dinyatakan bahawa disebabkan Smail memadamkan lampu, malam menjadi gelap. 


\section{Contoh 10}

P: [Smail] [avait] [éteint] [les lampes]. [La nuit] [était] [noire]. (hlm. 29)

[Smail] [telah] [memadamkan] [lampu]. [Malam] [telah] [gelap]

I: $\quad$ Smail had put out the lights. The night was dark. (hlm. 20)

M: Smail memasang pelita. Malamnya gelap. (hlm. 15)

Dapat dilihat bahawa dalam teks terjemahan bahasa Melayu, penterjemah telah melakukan pindaan, iaitu dengan menggantikan kata kerja put out, yang bermaksud "memadamkan", dengan kata kerja "memasang", yang mempunyai makna yang berlawanan dengan kata kerja "put out". Pindaan yang dilakukan menyebabkan teks terjemahan yang terhasil jelas berbeza sekali daripada kandungan teks sumber asal dalam bahasa Perancis dan teks perantara dalam bahasa Inggeris. Walau bagaimanapun, dalam hal ini, perbezaan yang wujud antara teks terjemahan dalam bahasa Melayu dengan teks asal dalam bahasa Perancis bukanlah disebabkan oleh teks perantara. Perlu ditekankan juga bahawa pindaan yang dibuat telah mengubah mesej yang ingin disampaikan. Berbeza sekali dengan mesej asal yang menyampaikan mesej bahawa perbuatan Smail memadamkan lampu pelita menyebabkan malam menjadi gelap, mesej dalam teks terjemahan bahasa Melayu menyampaikan mesej bahawa disebabkan malam yang gelap, Smail terpaksa memasang lampu pelita.

Kajian ini dilakukan untuk meneliti sama ada wujud perbezaan antara teks terjemahan dalam bahasa Melayu dengan teks sumber asal dalam bahasa Perancis disebabkan penggunaan teks perantara bahasa Inggeris dalam proses terjemahan tidak langsung. Secara amnya, teks terjemahan dalam bahasa Melayu menunjukkan persamaan dari segi kandungannya dengan teks sumber asal dalam bahasa Perancis. Walau bagaimanapun, terdapat perbezaan antara kandungan teks terjemahan dalam bahasa Melayu jika dibandingkan dengan teks sumber asal dalam bahasa Perancis, seperti yang ditunjukkan dalam contoh yang dipaparkan. Perbezaan dapat dilihat dalam bentuk penambahan, pengguguran dan pindaan yang terdapat pada teks terjemahan dalam bahasa Melayu jika dibandingkan dengan teks sumber asal dalam bahasa Perancis. Seperti yang dilihat dalam Contoh 1 hingga Contoh 5, perbezaan ini berlaku disebabkan penggunaan teks perantara. Secara khususnya, pergantungan penterjemah pada teks perantara yang telah disesuaikan melalui penambahan, pengguguran dan pindaan, seperti yang dilihat dalam Contoh 1 hingga Contoh 5, telah menyebabkan 
teks terjemahan yang terhasil juga berbeza daripada teks sumber asal dalam bahasa Perancis.

Walau bagaimanapun, terdapat juga perbezaan antara teks terjemahan bahasa Melayu dengan teks sumber asal dalam bahasa Perancis yang bukan disebabkan penggunaan teks perantara tetapi disebabkan penyesuaian yang dilakukan oleh penterjemah sendiri, seperti yang dipaparkan dalam Contoh 6 hingga Contoh 10 . Oleh itu, dapat disimpulkan bahawa sememangnya terdapat perbezaan dari segi kandungan teks terjemahan bahasa Melayu dan teks sumber bahasa Perancis dalam terjemahan tidak langsung. Walau bagaimanapun, perbezaan yang berlaku bukan disebabkan oleh penggunaan teks perantara semata-mata tetapi juga disebabkan oleh faktor penterjemah.

Perlu ditekankan juga bahawa walaupun kajian ini tidak meneliti kesan daripada perbezaan yang wujud antara teks terjemahan bahasa Melayu dan teks sumber asal dalam bahasa Perancis akibat penggunaan teks perantara bahasa Inggeris, beberapa pemerhatian dapat dibuat. Berdasarkan contoh yang dianalisis, dapat dilihat bahawa dalam beberapa keadaan, perbezaan antara kandungan teks terjemahan bahasa Melayu dan teks sumber asal dalam bahasa Perancis akibat penggunaan teks perantara bahasa Inggeris menyebabkan mesej yang disampaikan dalam terjemahan bahasa Melayu tidak sama malah berlawanan dengan mesej yang ingin disampaikan dalam teks asal dalam bahasa Perancis. Selain itu, terdapat juga mesej yang disampaikan dalam teks terjemahan dalam bahasa Melayu menjadi kurang terperinci jika dibandingkan dengan mesej dalam teks sumber asal dalam bahasa Perancis. Kesan seperti ini boleh diklasifikasikan sebagai kesan negatif akibat penggunaan teks perantara dalam terjemahan tidak langsung.

Meskipun demikian, perbandingan dan analisis yang dilakukan juga menunjukkan bahawa kadangkala perbezaan yang wujud tidak menjejaskan makna yang terkandung dalam teks sumber asal, malah terdapat perbezaan yang menyebabkan mesej yang disampaikan menjadi semakin jelas, khususnya yang melibatkan penyesuaian dalam bentuk penambahan. Dengan kata lain, melalui penyesuaian dalam bentuk penambahan, maklumat yang bersifat implisit dalam teks sumber bertukar menjadi eksplisit dalam teks terjemahan. Di samping itu, dapat dilihat juga bahawa terdapat perbezaan yang menyebabkan teks terjemahan dalam bahasa Melayu menjadi teks yang mempunyai konotasi yang lebih positif jika dibandingkan dengan teks sumber asal dalam bahasa Perancis, khususnya yang melibatkan penyesuaian dalam bentuk pindaan. Oleh itu, dapat dikatakan bahawa perbezaan antara teks terjemahan dan teks sumber asal tidak semestinya mempunyai kesan yang negatif, malah ada kalanya perbezaan ini menjadikan teks terjemahan lebih jelas dan lebih sesuai untuk pembaca sasaran. 


\section{KESIMPULAN}

Kajian ini meneliti pengaruh teks perantara dalam terjemahan tidak langsung, khususnya untuk menentukan sama ada penggunaan teks perantara dalam terjemahan tidak langsung mempunyai kesan terhadap kandungan teks terjemahan. Kajian ini mendapati bahawa perbezaan sememangnya wujud antara teks terjemahan dan teks sumber asal dalam terjemahan tidak langsung. Walau bagaimanapun, perbezaan yang berlaku ini bukan disebabkan penggunaan teks perantara semata-mata tetapi juga disebabkan penyesuaian yang dilakukan oleh penterjemah sendiri. Kajian ini juga mendapati bahawa kesan daripada penyesuaian ini tidak semestinya bersifat negatif, malah terdapat penyesuaian yang menjadikan teks terjemahan lebih sesuai untuk pembaca sasaran. Hal ini selaras dengan pendapat He (2001) dan Ringmar (2007) yang menyatakan bahawa terjemahan tidak langsung memainkan peranan yang positif, khususnya untuk menghubungkan budaya yang berbeza dan untuk memperkenalkan sastera daripada satu budaya kepada budaya yang lain. Kajian ini, walau bagaimanapun, terhad dari segi skopnya. Lebih banyak kajian perlu dilakukan tentang terjemahan tidak langsung, khususnya dalam konteks Malaysia, dengan melibatkan teks daripada pelbagai bahasa dan pelbagai genre supaya kita dapat mengetahui dengan lebih jelas peranan yang dimainkan oleh teks perantara dalam terjemahan tidak langsung, khususnya yang melibatkan penyampaian makna dalam terjemahan.

\section{PENGHARGAAN}

Penulis merakamkan penghargaan kepada Universiti Sains Malaysia (USM) yang telah membiayai penyelidikan ini di bawah Geran 'Bridging' Universiti Sains Malaysia (304.PHUMANITI.6316304).

\section{RUJUKAN}

Amener. (2002). Dlm. Kamus Perancis Melayu Dewan. Dewan Bahasa dan Pustaka.

Assis Rosa, A., Pięta, H., \& Maia, R. B. (2017). Theoretical, methodological and terminological issues regarding indirect translation: An overview. Translation Studies, $10(2), 113-132$.

Avoir. (2002). Dlm. Kamus Perancis Melayu Dewan. Dewan Bahasa dan Pustaka.

Blasted. (t.t.). Dlm. Oxford Learner's Dictionaries. Dicapai pada 4 Mac 2020 daripada https://www.oxfordlearnersdictionaries.com/definition/english/blasted?q=blasted

Crestfallen. (t.t.). Dlm. Oxford Learner's Dictionaries. Dicapai pada 4 Mac 2020 
PENGARUH TEKS PERANTARA DALAM TERJEMAHAN TIDAK LANGSUNG KEPADA BAHASA MELAYU

daripada

https://www.oxfordlearnersdictionaries.com/definition/english/ crestfallen?q=crestfallen

Dai. (t.t.). Dlm. Pusat Rujukan Persuratan Melayu, DBP. Dicapai pada 4 Mac 2020 daripada http://prpm.dbp.gov.my/Cari1?keyword=dai.

Doigt. (2002). Dlm. Kamus Perancis Melayu Dewan. Dewan Bahasa dan Pustaka.

Ému. (2002). Dlm. Kamus Perancis Melayu Dewan. Dewan Bahasa dan Pustaka.

Éteindre. (2002). Dlm. Kamus Perancis Melayu Dewan. Dewan Bahasa dan Pustaka.

Fauconnier, H. (1930). Malaisie. Paris: Librairie Stock.

Fauconnier, H. (2015). Nurani Tanah Melayu. Diterjemah oleh Muhammad Haji Salleh. Institut Terjemahan \& Buku Malaysia.

Fauconnier, H. (2015). The Soul of Malaya. Translated by E. Sutton. Singapore: Editions Didier Millet.

Filthy. (t.t.). Dlm. Oxford Learner's Dictionaries. Dicapai pada 4 Mac 2020 daripada https:// www.oxfordlearnersdictionaries.com/definition/english/filthy_1?q=filthy

Fumer. (2002). Dlm. Kamus Perancis Melayu Dewan. Dewan Bahasa dan Pustaka.

Harijan. (t.t.a). Dlm. Merriam-Webster Dictionary. Dicapai pada 4 Mac 2020 daripada https://www.merriam-webster.com/dictionary/harijan.

Harijan. (t.t.b). Dlm. Collins English Dictionary. Dicapai pada 4 Mac 2020 daripada https:// www.collinsdictionary.com/dictionary/english/harijan.

Haslina Haroon \& Melati Abdul Majid (2015). The translation of foreign novels into Malay by Dewan Bahasa dan Pustaka. Malay Literature, 28(1), 126-156.

He, C. (2001). Chinese translations of Henrik Ibsen. Perspectives: Studies in Translation Theory and Practice, 9(3), 197-214.

Hekkanen, R. (2014). Direct translation - Is it the only option? Indirect translation of Finnish prose literature into English. B.J. Epstein (Ed.), True North: Literary translation in the Nordic countries. Cambridge Scholars Publishing.

Hocher. (2002). Dlm. Kamus Perancis Melayu Dewan. Dewan Bahasa dan Pustaka. Indéfiniment. (2002). Dlm. Kamus Perancis Melayu Dewan. Dewan Bahasa dan Pustaka.

Kadiu, S. (2016). David Bellos' indirect translation of Ismail Kadare's "The file on H": A contextual analysis. International Journal of Literary Linguistics, 5(3), 1-24.

Kittel, H. \& Frank, A.P. (1991). Introduction. H. Kittel \& A.P. Frank (Eds.), Interculturality and the historical study of literary translations. Erich Schmidt Verlag.

Lampe. (2002). Dlm. Kamus Perancis Melayu Dewan. Dewan Bahasa dan Pustaka.

Landers, C.E. (2001). Literary Translation: A Practical Guide. Multilingual Matters.

Leur. (2002). Dlm. Kamus Perancis Melayu Dewan. Dewan Bahasa dan Pustaka.

Li, W. (2017). The complexity of indirect translation: reflections on the Chinese translation and reception of H. C. Andersen's tales. Orbis Litterarum, 72(3), 181-208.

Me. (2002). Dlm. Kamus Perancis Melayu Dewan. Dewan Bahasa dan Pustaka.

Muhammad Haji Salleh. (2015). Pengenalan, Suatu Kerusuhan. Nurani Tanah Melayu. Diterjemah oleh Muhammad Haji Salleh. Institut Terjemahan \& Buku Malaysia. 
Nida, E.A. 1964. Toward a science of translating, with special reference to principles and procedures involved in Bible translating. E.J. Brill.

Non. (2002). Dlm. Kamus Perancis Melayu Dewan. Dewan Bahasa dan Pustaka.

Opium. (2002). Dlm. Kamus Perancis Melayu Dewan. Dewan Bahasa dan Pustaka.

Paria. (2002). Dlm. Kamus Perancis Melayu Dewan. Dewan Bahasa dan Pustaka.

Paria. (t.t.a). Dlm. Pusat Rujukan Persuratan Melayu, DBP. Dicapai pada 4 Mac 2020 daripada http://prpm.dbp.gov.my/cari1?keyword=paria.

Paria. (t.t.b). Dlm. Merriam-Webster Dictionary. Dicapai pada 4 Mac 2020 daripada https:// www.merriam-webster.com/dictionary/pariah.

Parler. (2002). Dlm. Kamus Perancis Melayu Dewan. Dewan Bahasa dan Pustaka.

Pouvoir. (2002). Dlm. Kamus Perancis Melayu Dewan. Dewan Bahasa dan Pustaka.

Put out. (t.t.). Dlm. Oxford Learner's Dictionaries. Dicapai pada 4 Mac 2020 daripada https://www.oxfordlearnersdictionaries.com/definition/english/put-out?q=put+out

Respirer. (2002). Dlm. Kamus Perancis Melayu Dewan. Kuala Lumpur: Dewan Bahasa dan Pustaka.

Ringmar, M. (2007). Roundabout routes": Some remarks on indirect translations. F. Mus (Ed.), Selected papers of the CETRA research seminar in translation studies 2006. CETRA.

Sacré. (2002). Dlm. Kamus Perancis Melayu Dewan. Dewan Bahasa dan Pustaka.

Sec. (2002). Dlm. Kamus Perancis Melayu Dewan. Dewan Bahasa dan Pustaka.

Shuttleworth, M. \& Cowie, M. (1997). Dictionary of Translation Studies. St. Jerome.

Tu. (2002). Dlm. Kamus Perancis Melayu Dewan. Dewan Bahasa dan Pustaka.

Ton. (2002). Dlm. Kamus Perancis Melayu Dewan. Dewan Bahasa dan Pustaka. 